\title{
Chemistry Based on Renewable Raw Materials: Perspectives for a Sugar Cane-Based Biorefinery
}

\author{
Murillo Villela Filho, ${ }^{1}$ Carlos Araujo, ${ }^{2}$ Alfredo Bonfá, ${ }^{1}$ and Weber Porto ${ }^{3}$ \\ ${ }^{1}$ Department of Innovation Management Chemicals \& Creavis, Evonik Degussa Brasil Ltda., Alameda Campinas 579, \\ São Paulo, SP, Brazil \\ ${ }^{2}$ Department of Electrolysis Products \& Alcoxides, Evonik Degussa Brasil Ltda., Alameda Campinas 579, São Paulo, SP, Brazil \\ ${ }^{3}$ Department of Presidency, Evonik Degussa Brasil Ltda., Alameda Campinas 579, São Paulo, SP, Brazil
}

Correspondence should be addressed to Murillo Villela Filho, murillo.villela@evonik.com

Received 13 January 2011; Revised 28 February 2011; Accepted 6 March 2011

Academic Editor: Robert F. H. Dekker

Copyright (๑) 2011 Murillo Villela Filho et al. This is an open access article distributed under the Creative Commons Attribution License, which permits unrestricted use, distribution, and reproduction in any medium, provided the original work is properly cited.

Carbohydrates are nowadays a very competitive feedstock for the chemical industry because their availability is compatible with world-scale chemical production and their price, based on the carbon content, is comparable to that of petrochemicals. At the same time, demand is rising for biobased products. Brazilian sugar cane is a competitive feedstock source that is opening the door to a wide range of bio-based products. This essay begins with the importance of the feedstock for the chemical industry and discusses developments in sugar cane processing that lead to low cost feedstocks. Thus, sugar cane enables a new chemical industry, as it delivers a competitive raw material and a source of energy. As a result, sugar mills are being transformed into sustainable biorefineries that fully exploit the potential of sugar cane.

\section{Introduction}

In a market economy, corporations aim to maximize profit. Governments or society in general impose constraints on and regulate the maximization of profit. Product quality, operational safety, and respect for the environment all have to be fulfilled. To maximize profit, the chemical industry always seeks the most competitive feedstock. When competitive feedstock is available, opportunities for new processes and technologies arise. Technology for converting carbon dioxide into a feedstock source has been developed and used in Brazil since the inception of Pro-álcool, the Brazilian national alcohol program, in the 1970s [1]. Given the legislation, the market demand for sustainable products, and the progress being made in biotechnology and catalysis, developers are working on new processes, which are giving rise to a wide range of biobased products. The old sugar mills (engenhos) have become efficient industrial facilities (usinas) that produce sweeteners, ethanol, and bioenergy. Recent developments involve transforming sugar mills into biorefineries. Besides sweeteners, biofuel, and bioenergy, the biorefineries will be able to produce bioplastics and other chemicals by using the whole cane via alcohol chemistry and fermentative routes. This essay analyzes the industry's historical response to new developments stemming from the rise of competitive feedstock and the opportunities that it creates. It focuses on sugar cane, its availability as a feedstock source, and the technologies that can turn sugar cane into an important starting point for chemistry of the future. Based on recent examples of processes and market developments, a new arrangement of integrated agroindustry, processing sugar cane and yielding higher value products, is foreseen-a sugar cane biorefinery.

\section{The Chemical Industry and the Quest for Feedstock}

2.1. Competitive Feedstock. The history of the chemical industry is one of developing new processes for using the most competitive feedstock. Competitive feedstocks make it possible to reach the lowest process cost and are available in 
quantities compatible with world-scale production. In early times, chemistry was based on natural products. The most important technology was the extraction and purification of a target compound. Production was characterized by a small production scale. This was because access to feedstock was restricted, often in foreign lands [2]. Discoveries made new natural feedstocks available, thus giving rise to new products. In the 19th century, during the Industrial Revolution, demand was high for coal, which was used to fire the steam engine. As a result, coal exploration was widespread, making coal abundant at low prices. The chemical industry recognized the opportunity. Chemistry based on coal grew as a discipline. Transformation yielded many products, such as organic dyes and pigments. It was not by chance that the chemical industry was established in regions where demand for industrial coal was high, such as Germany. However, production scale still reflected only regional demand and transformation was expensive, not to mention the expensive mining operations. Coal-based chemistry dominated until World War II [3]. In the second half of the 20th century, large-scale automobile consumption led to a high demand for fossil-based fuels. As a consequence, crude oil production improved enormously and huge refineries went on stream in order to provide fuel for individual mobility [4]. Again, the chemical industry recognized the opportunity in the new feedstock. Using by-products from the refineries made it possible to use inexpensive production processes. Petrochemistry was thus born. It is today's most important source of raw materials for the chemical industry. Its characteristics are world-scale production and highly integrated processes. Limitations include costly investment in equipment [4]. Moved by the awareness that it is consuming finite resources and climate change, society is searching for alternative feedstocks. One possibility is the use of carbohydrates.

Nowadays, carbohydrates are largely available worldwide. Improvements in agricultural technology, precision agriculture and plant biotechnology enable high-scale production of carbohydrate at lower cost. New agricultural frontiers and further technological development point to further production growth. Thus, it will be possible to use carbohydrates for both food and chemistry. As an example, Brazilian grain production increased at the same time as bioethanol production [5-7].

Besides their wide availability, carbohydrates are also renewable, in contrast to finite fossil feedstock. All carbon comes from atmospheric carbon dioxide under fixation during photosynthesis. In this process, carbon dioxide and water are transformed into biomass and oxygen, consuming light energy. If a biorenewable feedstock is used as the source of carbon, fossil carbon is not released into the atmosphere. Thus, there is no direct contribution to green house gas production [8].

Table 1 shows the comparison of petrochemicals and biorenewables based on carbon content. The opportunity for the chemical industry offered by carbohydrates can be seen.

The first relevant information is the comparative availability of petrochemicals and sugar cane-based products. This is important in view of the impact of a new process on the price of the feedstock. The second information is

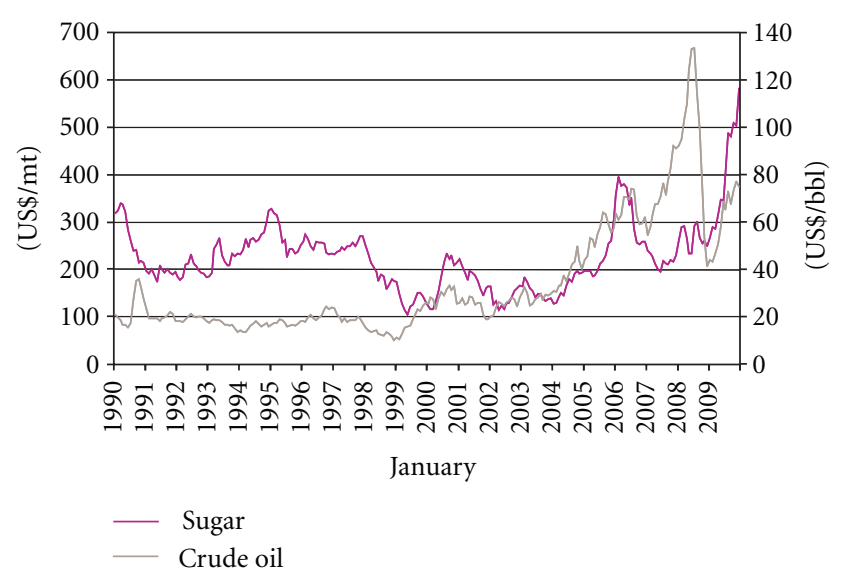

FIGURE 1: Sugar price (US $\$ / \mathrm{mt}$ ) compared to crude oil price (US\$/bbl) evolution, source: NYBOT.

the comparative price for carbon in petrochemicals and biorenewables. To analyze the opportunity for the chemical industry, one needs a comparison based on the price for carbon, since this is the actual base of chemistry.

Not only the present price is important in evaluating prices, but also the long-term perspective. Crude oil reached a record-high price of US\$ 140 in the second half of 2008, and prices are increasing again after the economical crisis. The engine driving this development is the situation known as "peak oil." Starting from zero, production grows over time until it peaks. Then, production irreversibly declines at the same rate at which it grew [9, 10]. Such a development can lead to constant high prices. A projection by the International Energy Agency (IEA) suggests that the production of conventional crude oil reached its peak in 2006, at about 70 million barrels a day [11]. The Energy Information Agency (EIA) estimates that the crude oil barrel price will lie between US\$80 and US\$100 on the next years [12].

Prices for biorenewables fluctuate due to several factors, including weather. Every time, however, the price is high, there is a trend to overproduction, limiting the price peak to some ranges. Figure 1 shows price evolution of sugar and crude oil from 1990 until 2009.

Not only the abundance and the price make a feedstock competitive. It is also necessary to have the technology to transform it to the desired product under economic conditions. Sugar cane can be converted into chemicals via biotechnological (fermentative) or chemical (alcohol-based catalysis) processes. Both offer a new paradigm for the economy of scale. The development and implementation of new processes, however, are very expensive. Perhaps we are reaching the time when expenses are overcompensated by the better economic performance of biorenewables.

2.2. Bio-Based Products and Sugar Cane. Competitive feedstock and transformation technology are necessary, but not sufficient for a product to be successful. Market acceptance is fundamental to a product. This deals with price, performance, and image. 
TABLE 1: Feedstock comparison based on carbon content.

\begin{tabular}{lccccccc}
\hline & Formula & $\begin{array}{c}\text { Production } \\
(\text { million} \cdot \mathrm{mt} / \mathrm{a})\end{array}$ & $\begin{array}{c}\text { Price } \\
(€ / \mathrm{t})\end{array}$ & $\begin{array}{c}\mathrm{C} \\
(\%)\end{array}$ & $\begin{array}{c}\mathrm{H} \\
(\%)\end{array}$ & $\begin{array}{c}\mathrm{O} \\
(\%)\end{array}$ & $\begin{array}{c}\text { Carbon } \\
(€ / \mathrm{mt} \mathrm{C})\end{array}$ \\
\hline $\begin{array}{l}\text { Petrochemicals } \\
\text { Ethylene }\end{array}$ & $\mathrm{C}_{2} \mathrm{H}_{4}$ & 110 & 875 & 86 & 14 & & 1017 \\
Propylene & $\mathrm{C}_{3} \mathrm{H}_{6}$ & 75 & 778 & 86 & 14 & & 905 \\
Benzene & $\mathrm{C}_{6} \mathrm{H}_{6}$ & 45 & 576 & 92 & 8 & & 626 \\
$\quad \begin{array}{l}\text { Naphta } \\
\text { Biorenewables }\end{array}$ & $\mathrm{C}_{n} \mathrm{H}_{2 n}$ & 362 & 416 & 86 & 14 & & 484 \\
$\quad$ & & & & & & & \\
Sucrose & $\mathrm{C}_{12} \mathrm{H}_{22} \mathrm{O}_{11}$ & 172 & 326 & 42 & 6 & 52 & 476 \\
Bioethanol & $\mathrm{C}_{2} \mathrm{H}_{6} \mathrm{O}$ & 39 & 326 & 52 & 13 & 35 & 627 \\
\hline
\end{tabular}

Prices as of September, 2009, €1 = US\$1.42.

References: Naphtha Europe, Propylene Europe, Ethylene Europe, Benzene Europe, Sugar Contract number 11, Ethanol (Hydrous) Brazil.

Recent studies suggest that biobased products already enjoy market demand. For instance, over a third of Americans and Europeans can be considered "green thinkers" who actively seek and pay more for green products [13]. Opinion research in Brazil leads in the same direction [14]. Nevertheless, a biobased product must perform comparably to other products of the same price. Thus, Brazilian cars are filled with ethanol if it does not exceed $70 \%$ of gasoline price $[15,16]$.

Among the established carbohydrate sources, sugar cane is currently the one showing the best performance. The first reason is attributable to the efficient biochemical photosynthesis pathway, the $\mathrm{C}_{4}$ route [17]. Secondly, it grows in a tropical environment with sun and water, which are abundant throughout the year. Further, its soluble carbohydrate (sucrose) is ready to use [1]. Over the last 30 years, the development of biofuel technology for production enabled a mature technology for a sugar cane-based economy. Another fundamental aspect is the use of the whole crop, which amounts to a very positive energy balance and the lowest carbon footprint [18]. Besides the sugar, the energy for the sugar mill is obtained from bagasse, the fiber residue from sugar cane after the milling process. On top of that, its energy efficiency is much higher than that of corn and wheat [19], as shown in Figure 2. For these reasons, sugar cane can be considered the green crude, and is capable of supplying the carbon needed by the market at competitive prices and with the sustainability demanded by the society.

2.3. Sugar Cane Processing Development. Although a very significant development in sugar cane technology was noted with Pro-álcool in 1975, the beginning of the development dates back to the 16th century [1]. In 1532, Martim Afonso de Souza introduced sugar cane in Brazil. The Portuguese conqueror brought the technology from Madeira and Azores Islands. From the 16th century until 1930s, sugar cane agriculture focused on sweeteners production, although some spirits were also distilled for consumption in the colony. The sugar mills used man or animal power to extract sugar juice, and production was characterized by low technology [1] In 1930, the sugar mills were transformed into usinas when Brazilian president Getúlio Vargas determined the addition

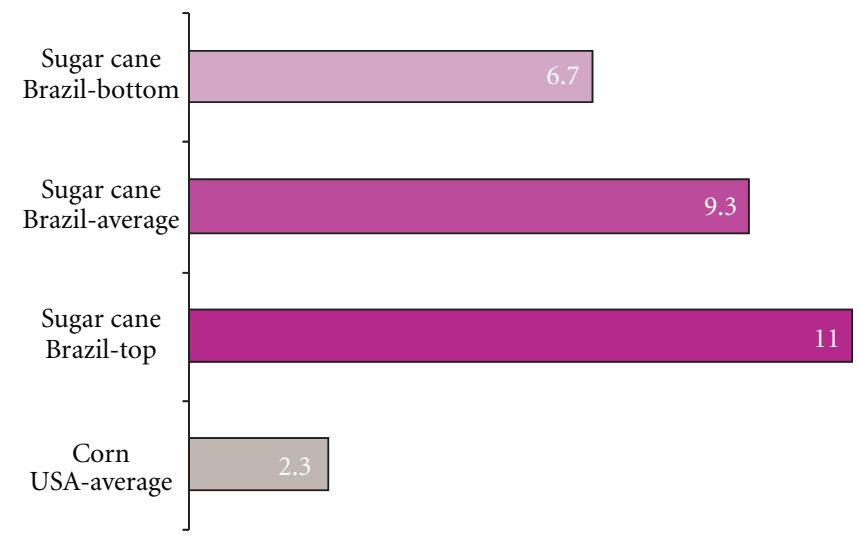

Source: [18], USDA 2010

FIGURE 2: Energy efficiency of sugar cane ethanol (bottom), sugar cane ethanol (average), sugar cane ethanol (top), and corn ethanol (USA average) productions: energy efficiency expressed as ratio BOE output/BOE input, $\mathrm{BOE}=$ barrel of oil equivalent (Source: [18], [20]).

of $5 \%(\mathrm{v} / \mathrm{v})$ of ethanol to gasoline, leading to a mix of products: sugar and ethanol. From 1930s until 1990s the traditional usinas produced sugar, ethanol from molasses, and used the bagasse to produce steam [21].

In the 1990s the Brazilian energy market was liberalized [22], opening a new outlet opportunity for sugar cane processors. The bagasse surplus present in the usina could be converted into bioelectricity in high-pressure boilers [8]. The energy could be sold to the grid. Besides, at the same time, the sugar sector in Brazil was deregulated. As a consequence, innovation turned to be the best way for usinas to increase profitability. Since then, the modern usinas produce sweeteners, biofuel and bioenergy. The simplified flowchart of a modern usina is shown in Figure 3.

\section{Routes for Chemicals from Sugar Cane}

The production of chemicals based on sugar cane is achieved by two different routes: alcohol chemistry and fermentative routes. Both will be discussed in detail. 


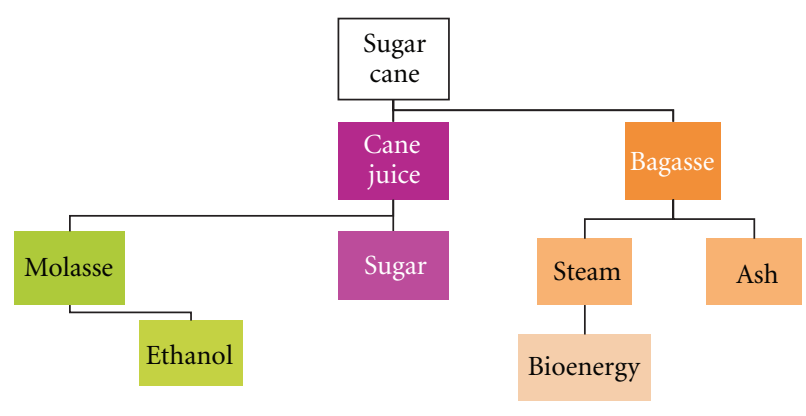

Figure 3: Flowchart of a modern usina.

3.1. The Alcohol Chemistry Route. The alcohol chemistry route combines two successful technologies: alcohol fermentation and catalytic processes. Alcohol fermentation has been known since 7,000 B.C.; its efficiency suppressed the petrochemical route of ethanol production. The catalytic processes are the heart of modern chemical industry. High yields are possible at high temperatures and pressure and with expensive investment to drive reaction in the desired direction. A comparison of alcohol chemistry and petrochemical routes shows lower sensitivity to economy of scale for the former.

Many biobased products can be obtained from ethanol via the alcohol chemistry route. The ethylene production from alcohol opens the door to bioplastics production. Salgema produced 100 kilotons per year ethylene based on alcohol in the 1980s for the dichloroethene/polyvinyl chloride (DCE/PVC) production. The production was abandoned due to low crude oil prices in the 1980s, which inhibited the competitiveness of this technology [23]. Ethylene is a precursor of several plastics (e.g., PE, PVC, PVA, polystyrene), and its world market was 128.0 million metric tons in 2008 [24]. Recently, Braskem, DOW and SOLVAY INDUPA renewed the world's attention to the production of bioethylene [25]. Braskem S.A. started production of biopolyethylene in Triunfo-RS, Brazil, in 2010. DOW Brasil $S$.A. announced that it would continue its plan for fully integrated production of polyethylene starting from sugar cane in Minas Gerais, Brazil, and Solvay Indupa S.A.I.C. is going to produce PVC from ethanol in its site in Santo André-SP, Brazil [26-28]. The total announced bioplastic production will require 2 million tons of sugar.

Tires can also be made from sugar cane. Synthetic rubber for tire production is made from butadiene, which can be obtained through the catalytic conversion of alcohol. This process was developed in Russia in the early 20th century. The Lebedev process was modified by Carbide and Carbon Chem Corp (USA) in the 1940s. The aim of production was to supply the U.S. Army with tires during World War II [29]. The butadiene production from ethanol was also carried out in Brazil (by Coperbo) from 1967 to 1986 with 27.5 kilotons per year capacity. The yield of the processapproximately $70 \%$ - and the comparatively high ethanol price in the 1980s limited the process's economic attractiveness [30, 31]. Approximately 350 kilotons of synthetic rubber containing butadiene were produced in Brazil in 2007 [32].
This rubber is made of oil because natural latex is much more expensive. These tires can be produced once again from biorenewable feedstock. Currently there is favorable demand for biomaterials in the automotive industry (market pull). At the same time, improvements in the catalytic reaction selectivity (technology push) can enhance economic attractiveness again.

Further alcohol chemical routes start with the oxidation of ethanol. It yields acetaldehyde, which is an important chemical intermediate for the production of several chemicals, such as acetic acid, peroxiacetic acid, acetic anhydrid, butanol, keten-deketen, crotonaldehyde, pentaerythritol, chloral, pyridine, and acetic esters. This way, ethanol reaches through chemistry different markets in many applications: agricultural, food and packaging, construction, coatings and inks, cosmetics and pharmaceuticals. The oxidation of ethanol and the production of alcohol-based solvents are carried out by Rhodia Brasil Ltda. in Paulinia-SP, Brazil [33].

Ethylic ethers are a further class of products derived from ethanol. Ethyl tert-butyl ether (ETBE) is an oxygenate gasoline additive that can replace methyl tert-butyl ether (MTBE) [34]. It can be a renewable portion of fuel, which conforms with European legislation and is preferred by the mineral oil industry to other biorenewable fuels, such as the direct addition of ethanol to gasoline. As its production requires isobutylene, it is unlikely to take place at the usina. Braskem S.A. produces in Triunfo-RS, Brazil, 212 kilotons per year of ETBE for the export market [35]. Moreover, diethyl ether can also be obtained from ethanol. It is an important solvent for the chemical industry, used in the production of cellulose plastics, for example, cellulose acetate.

3.2. The Fermentative Route. The fermentative route is based on the conversion of carbohydrate (sugar) by a microorganism to the desired compound. The classical example is ethanol fermentation. The fermentative route is characterized by completely different conditions from the traditional chemical production, thus requiring a different equipment setup. For example, the fermentation is traditionally conducted between $30^{\circ} \mathrm{C}$ and $37^{\circ} \mathrm{C}$ and atmospheric pressure. Although in many cases the equipment must be designed to support sterilization, these are mild conditions compared to petrochemical processes. Therefore, the value of necessary equipment investment is considerably lower. A further important difference is related to the purification steps. In the fermentative route, many transformation steps are carried out by one single microorganism and in one single reaction vessel. Consequently, fewer purification steps are required. The process setup is also flexible regarding biological improvement; that is, continuous improvement of the microorganism is possible without any necessary modification to the equipment during production life time. On the other hand, the development of a microorganism exacts a high price for R\&D before commercial production may start. The differences to the classical equipment setup allow a paradigm change as regards the economy of scale for fermentative processes. 


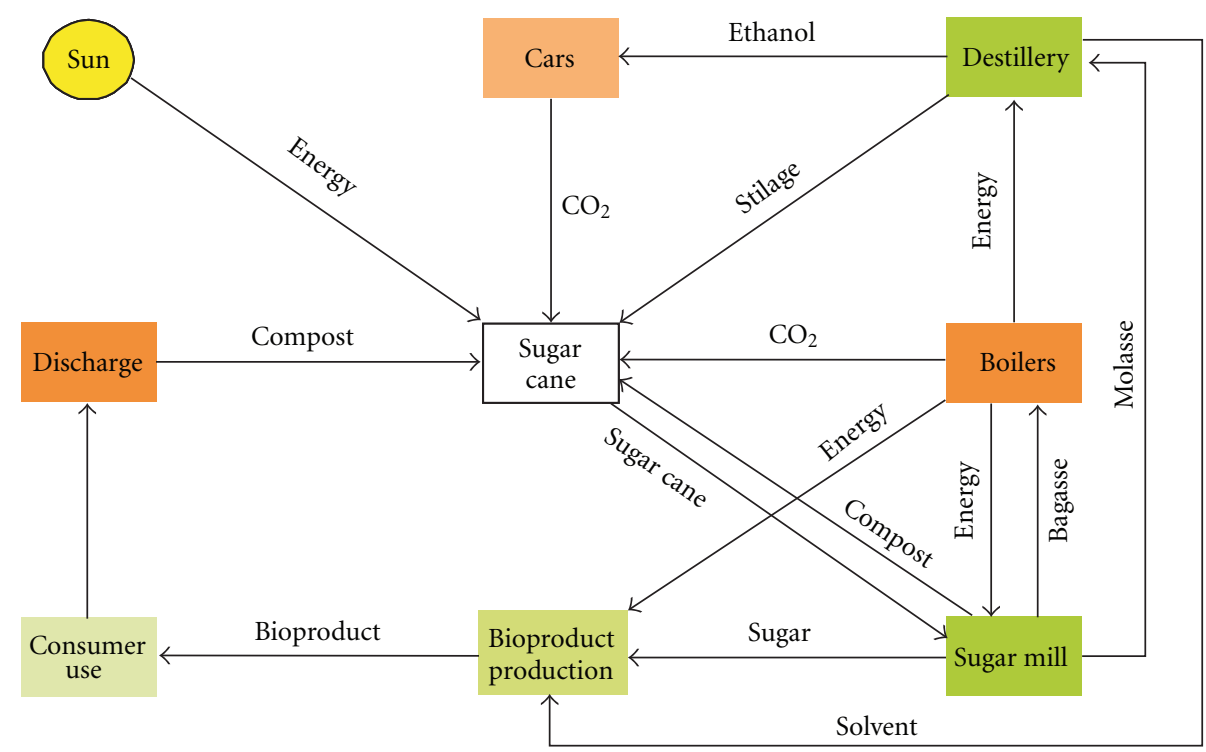

FIGURE 4: Biorefinery concept: in an efficient biorefinery, mass and energy flow are integrated and recycled in order to provide the maximum efficiency and the lowest cost; the integration into agriculture enables waste streams to be reused in cane plantation and $\mathrm{CO}_{2}$ to be recycled via photosynthesis.

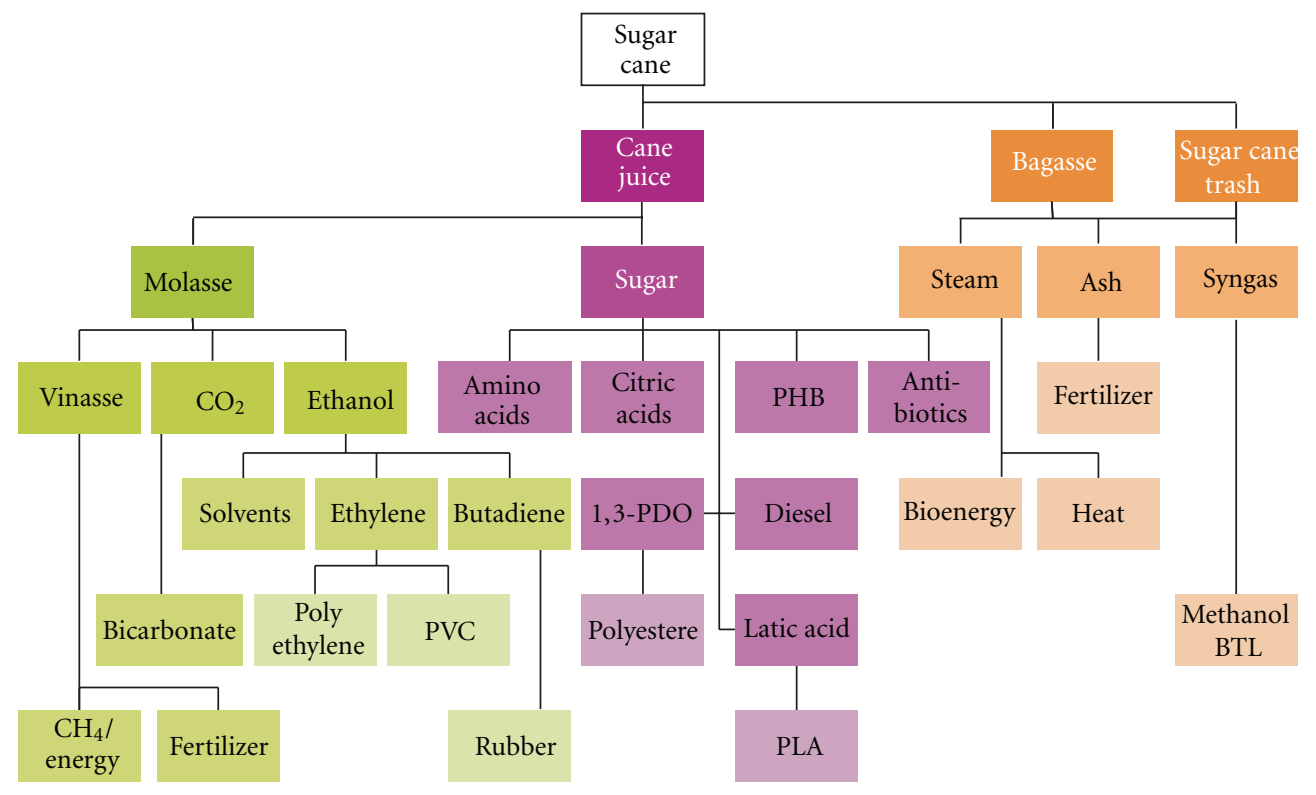

Figure 5: Example of biorefinery flowchart.

The fermentative route has profited from recent developments in biotechnology, such as metabolic engineering, proteomics, and metabolomics. These developments enable debottlenecking or even the construction of new pathways in microorganisms. As a consequence, process performance can be significantly enhanced. Some examples of chemicals from fermentative production will be presented briefly.

Biodegradable plastics can be produced via the fermentative route. Poly(hydroxy-butyrate) (PHB) is a biopolymer obtained from sugar cane through a fully renewable concept. Sugar is the substrate for fermentation, a process that enables the microorganism to accumulate the polymer. The cells are harvested at the end of fermentation and the polymer is recovered from biomass. The production of copolymers is also possible. PHB biodegradability enables special applications, for example, tubes for culture of seedlings, which degrade after the seedling is planted. Biocycle- $\mathrm{PHB}$ Industrial $S A$ has a pilot plant of $\mathrm{PHB}$ production fully integrated in a usina using the bagasse as energy [36].

Another example of fermentative production of chemicals is done on an industrial scale by DuPont (E. I. du Pont de Nemours and Company). At this company, fermentation products are used as a chemical platform. Bio-PDO (1,3propanediol) is produced via a synthetic biochemical route. 
In a subsequent step, the diol undergoes a reaction for polyester formation, yielding a high performance polymer that performs in the same way as the polymer produced via the traditional chemical route [37]. The production facility is located in the USA, where corn is used as source of carbohydrate. Nevertheless, sugar from sugar cane could be used instead of corn glucose.

Amino acids are also produced via the fermentative route. They are constituent of protein. Some aminoacids are therefore important feed additive. As protein constituents, amino acids are used by the pharmaceutical industry in the preparation of parenteral nutrition. Other amino acids have important applications in the food industry $[38,39]$. In Brazil, 200 kilotons per year of the amino acid lysine were produced in 2008 for animal nutrition [40]. The amino acid production is an example of how genetic engineering increases the competitiveness of the fermentative route. Thus, Evonik Degussa GmbH succeeded in producing amino acids on a commercial scale by fermentation. In the past, the amino acids were obtained by the hydrolysis of protein containing animal products $[41,42]$.

Solvents can also be obtained by fermentation. The fermentation of wild type Clostridium yields a mixture of solvents containing acetone, butanol and ethanol (ABE). ABE industrial technology was developed by Chaim Weizmann in 1916 for the acetone production. The ABE fermentation process was used in Eastern Europe, South Africa and China on an industrial scale until the 1990s [43]. The products find application as chemical building block, solvents and biofuel. The process has natural limitations like the products mixture, the maximum final yield and concentration, combined with high energy demand for purifying the products. Nevertheless, ongoing industrial development (Butamax Advanced Biofuels $L L C$ as joint-venture from DuPont \& $B P$ ) is opening up new perspectives for this process. Several patents have been applied for the exclusive production of Butanol to be used as renewable fuel additive $[44,45]$.

3.3. Further Developments. Besides existing processes, we can observe the intense development of new processes. This fact is coherent, given the assumption that the competitiveness of biorenewable feedstock is increasing. One important example is the company Amyris. Amyris Biotechnologies Inc. developed a pathway to obtain renewable diesel and jet fuel from sugar cane by fermentation. The substance called "farnesene" can now be produced by genetically engineered yeast. A pilot-scale production facility is located in Campinas-SP, Brazil, while an industrial scale production usina is under construction in Pradopolis-SP, Brazil $[46,47]$.

Another new development is the gasification of bagasse and sugar cane trash (includes cane tops and stalk leaves) that yields biomass-to-liquid (BTL). Bagasse and sugar cane trash are abundant at the usinas, and its gasification leads to syngas. From syngas it is possible to obtain liquid fuels, methanol, hydrogen and other substances via catalytic reactions [48]. This technology replaces fossil fuel by renewable biomass. However, the industrial application is limited by the economics.
Beyond the described activities, many other companies and partnerships participate in this technological development, for example, DSM/Roquette, Novozymes/Cargill, Shell/ Virent, Genencor/DuPont and Perstorp [49-53]. As confidentiality is necessary to enable advantages, the announcements represent only a small fraction of research activities, so much more has not been disclosed.

\section{Sustainability and Production Facilities}

One of the major drivers for the market acceptance of biobased products is consumers' awareness of climate change. Therefore, it is fundamental for biobased products to feature their ability to reduce the carbon footprint. Moreover, the present development anticipates future environmental protecting legislation. Thus, proactive action will provide a competitive advantage.

The biobased production, when integrated in a usina to form a biorefinery, enables highly sustainable processes. On one hand, sugar cane provides a highly efficiently exploited source of carbon for the chemical industry. Sugar cane agriculture has been deemed more sustainable than other comparable feedstock sources such as corn [19]. On the other hand, the use of bagasse and sugar cane trash as source of energy for the process, which avoids the use of fossil fuels, has a further positive impact on the carbon footprint. Figure 4 shows the concept of a biorefinery.

One example is the production of bioplastics from sugar cane in a biorefinery. The industry average carbon dioxide emission is $1.8 \mathrm{~kg}$ of $\mathrm{CO}_{2}$ eq. per $\mathrm{kg}$ of polyethylene produced from conventional resources [54], while for polyethylene from sugar cane it is $2.1 \mathrm{~kg}$ of $\mathrm{CO}_{2}$ eq. per $\mathrm{kg}$ of polyethylene [55], because when sugar cane grows, it captures carbon dioxide. This way, the total avoided emission is $3.9 \mathrm{~kg}$ of $\mathrm{CO}_{2}$ eq. per $\mathrm{kg}$ of polyethylene.

\section{Conclusion and Outlook}

We can see the production of chemicals based on carbohydrates, especially on sugar cane, accelerating. Old processes are being operated anew, new processes are going on-stream and $\mathrm{R} \& \mathrm{D}$ is taking on an impressive dimension. Thus, we can assume that in the future, sugar cane will be used to produce a wide range of products: sweeteners, biofuel, bioenergy, bioplastics and other chemicals. At the same time, the vision of the usinas being established at sites where many sugar cane-based processes are integrated is becoming a reality. This is possible, as the production integration into a biorefinery enhances the competitiveness of bioprocesses. The possibilities of inclusion in a biorefinery flowchart are shown in Figure 5. As there is a wide range of processes and products, the combination of routes is possible, which allows the biorefinery to be very flexible.

The enormous perspectives for biobased production and biorefineries correlate with corresponding challenges. An important question to be answered is: who are going to be the players able to manage all the relevant issues? According to a study published by McKinsey, successful players will 
be companies with a strategic fit to the biobased chemical business, with a competitive advantage through Intellectual Property, fermentation know-how, market intelligence, with competence in access to feedstock, metabolic and genetic engineering, fermentation stream know-how, downstream processing, processing capacity, product integration, marketing and distribution, and with conditions for high R\&D investments [56]. We should remember that the development may take 10 years to reach the market. To cope with all challenges, partnering along the value chain is an option that should be used frequently.

At present, we can observe that $\mathrm{R} \& \mathrm{D}$ centers are often located in the USA and Europe, but there are increasing activities in Brazil, too. For production, Brazil is the most economically attractive choice due to its superior sugar cane economics, well-developed infrastructure, timing and availability of greenfield opportunities, but there are also opportunities in China, some countries of Southeast Asia and of Africa [56].

It is undeniable that sugar cane has its own chemistry. Sugar cane delivers a competitive raw material and energy to the chemical industry. Usina production integration allows its transformation into a biorefinery that can use all the sugar cane potential. There is already an existing market for sugar cane-based chemistry. Alcohol chemistry products, amino acids, bioplastics, solvents and many other products are enjoying growing market demand, favored by the growing number of "green thinker" consumers, who are willing to consume biobased products made, for example, from sugar cane. New options regarding the economy of scale and new technologies make biobased products economically attractive, as proved by many investments on the sugar cane value chain in recent time. Brazil has an outstanding position, where the development of the technology and processes for sugar cane-based products is already taking place.

\section{References}

[1] J. R. Miranda, História da cana de açúcar-History of sugarcane, Komedi, Campinas, Brazil, 2008.

[2] O. Krätz, 7000 Jahre Chemie, Georg D. W. Callwey, München, Germany, 1990.

[3] R. N. Shreve and J. A. Brink, Chemical Process Industries, McGraw-Hill, New York, NY, USA, 4th edition, 1977.

[4] G. Alfke, W. W. Irion, and O. S. Neuwirth, Ullmann's Encyclopedia of Industrial Chemistry: Oil Refining, Wiley-VCH, Weinheim, Germany, 7th edition, 2010.

[5] Instituto Brasileiro de Geografia e Estatística (IBGE), "Levantamento sistemático da produção agrícola," Lavouras, December 2010, http://www.ibge.gov.br/home/estatistica/indicadores/agropecuaria/lspa/lspa_201012comentarios.pdf.

[6] União da Indústria de Cana-de-açucar (ÚNICA), "Dados e cotações-estatísticas: Produção de etanol no brasil," January 2011, http://www.unica.com.br/dadosCotacao/estatistica/.

[7] M. C. Gordinho, From Alcohol to Ethanol: A Winning Trajectory, Editora Terceiro Nome, São Paulo, Brazil, 2010.

[8] I. C. Macedo, Ed., Sugar Cane's Energy-Twelve studies on Brazilian sugar cane agribusiness and its sustainability, Berlendis \& Vertecchia, São Paulo, Brazil, 2005.
[9] M. K. Hubbert, Nuclear Energy and the Fossil Fuels. Drilling and Production Practice, American Petroleum Institute, Washington, DC, USA, 1956.

[10] L. Maugeri, "Oil: never cry wolf — why the petroleum age is far from over," Science, vol. 304, no. 5674, pp. 1114-1115, 2004.

[11] J. C. Rudolf, "Is 'Peak Oil' Behind Us? Green Blog," The New York Times, November 2010.

[12] EIA. Energy Information Agency, "Annual Energy Outlook 2011 Early Release Overview," 2010.

[13] "Datamonitor/Euromonitor," 2008.

[14] G. Varanda, De olho no mercado verde. Planeta Sustentável, Editora Abril S.A., São Paulo, Brazil, 2008.

[15] E. Magossi, "Etanol está competitivo apenas em MT e GO; indiferente em SP," Jornal O Estado de São Paulo, February 2011.

[16] IG São Paulo, "Calcule o que é melhor: álcool ou gasolina," January 2011, http://economia.ig.com.br/financas/orcamentofamiliar/calcule+o+que+e+melhor+alcool+ou+gasolina/ n1237603303738.html.

[17] M. Pessarakli, Handbook of Photosynthesis, Marcel Dekker, New York, NY, USA, 1997.

[18] I. C. Macedo, J. E. A. Seabra, and J. E. A. R. Silva, "Green house gases emissions in the production and use of ethanol from sugarcane in Brazil: the 2005/2006 averages and a prediction for 2020," Biomass and Bioenergy, vol. 32, no. 7, pp. 582-595, 2008.

[19] S. C. de Vries, G. W. J. van de Ven, M. K. van Ittersum, and K. E. Giller, "Resource use efficiency and environmental performance of nine major biofuel crops, processed by firstgeneration conversion techniques," Biomass and Bioenergy, vol. 34 , no. 5, pp. 588-601, 2010.

[20] United States Department of Agriculture, "2008 Energy Balance for the Corn-Ethanol Industry," Agricultural Economic Report 846, June 2010.

[21] J. N. Netto, A saga do álcool, Novo Século Editora, Osasco, Brazil, 2007.

[22] N. J. de Castro, R. Brandão, and G. A. Dantas, "A bioeletricidade sucroenergética na matriz elétrica," in Etanol e bioeletricidade, a cana-de-açucar no futuro da matriz energética, L. L. Souza and I. C. Macedo, Eds., Luc Projetos de Coordenação, São Paulo, Brazil, 2010.

[23] J. Finguerut, Personal communication, 2007.

[24] M. T. Devanney, "SRI Consulting - CEH Marketing Research Report-Ethylene," 2009.

[25] J. H. Schut, "What's Ahead for 'Green' Plastics," Plastics Technology, February 2008.

[26] S. A. Braskem, Braskem \& Toyota Tsusho start joint marketing activities for green polyethylene from sugar cane in Asia, São Paulo, Brazil, September 2008.

[27] S. A. Dow, Dow and Crystalsev Announce Plans to Make Polyethylene from Sugar Cane in Brazil, São Paulo, Brazil, July 2007.

[28] S. A. Solvay, Solvay Indupa will produce bioethanol-based vinyl in Brasil \& considers state-of-the-art power generation in Argentina, Brussels, Belgium, December 2007.

[29] Ullmanns Encyclopädie der technischen Chemie, Urban \& Scwhazenberg, Berlin, Germany, 3rd edition, 1958.

[30] Bioetanol de cana-de-açúcar: energia para o desenvolvimento sustentável. Organização BNDES e CGEE, BNDES, Rio de Janeiro, Brazil, 2008.

[31] P. C. Ravaglia, Estudo preliminar de reativação de unidade de produção de butadieno a partir de etanol, thesis, Universidade Federal do Rio de Janeiro, 2006. 
[32] Associação Brasileira da Indústria Química (ABIQUIM), "Anuário da Indústria Química Brasileira Edição," 2008.

[33] Rhodia Brasil Ltda, Rhodia Showcases Novelties to Strengthen Operation in Sustainable Solvents Area, São Paulo, Brazil, August 2009.

[34] E. Linak, H. Janshekar, and M. Yoneyama, "SRI Consulting Gasoline Octane Improvers/Oxygenates," November 2009.

[35] S. A. Braskem, Braskem inaugurates two plants in Bahia, São Paulo, Brazil, August 2009.

[36] "Biocycle-PHB Industrial S/A," Serrana, Brazil, Information Material, 2009.

[37] E. I. du Pont de Nemours and Company, DuPont Data Book, E. I. du Pont de Nemours and Company, Wilmington, Del, USA, 2006.

[38] J. Moski, "Yes, MSG, the Secret Behind the Savor," The New York Times, March 2008.

[39] European Food Safety Authority (EFSA), "Opinion of the Scientific Panel on food additives, flavourings, processing aids and materials in contact with food (AFC) related to a new long-term carcinogenicity study on aspartame," The EFSA Journal, vol. 356, pp. 1-44, 2006.

[40] Associação Brasileira da Indústria Química (ABIQUIM), "Anuário da Indústria Química Brasileira Edição," 2009.

[41] M. Kottenhanh, "Switching Technologies to create essentials," European Business Journal, pp. 44-46, 2007.

[42] Evonik Degussa GmbH, "About Rexim® amino acids - Production," January 2011, http://www.rexim.fr/product/rexim/ en/about/technologies/production/Pages/default.aspx.

[43] D. T. Jones and D. R. Woods, "Acetone-butanol fermentation revisited," Microbiological Reviews, vol. 50, no. 4, pp. 484-524, 1986.

[44] Butamax Advanced Biofuels LLC, Butamax Advanced Biofuels LLC Fact Sheet, Wilmington, Del, USA, 2010.

[45] K. Brekke, "Butanol, an Energy Alternative?" Ethanol Today, pp. 36-39, March 2007.

[46] Amyris Brasil Pesquisa e Desenvolvimento Ltda, "Amyris opens renewable products demonstration facility in Brasil," June 2009.

[47] Amyris Biotechnologies Inc, "Amyris and São Martinho announce construction manager selection and start of site preparation for Joint Venture industrial plant," Campinas, Brasil, and Emeryville, Calif, USA, December 2010.

[48] F. Geldsetzer and BtL Verfahren, Thieme Römpp Chemielexikon, Georg Thieme, Stuttgart, Germany, 2008.

[49] Royal DSM NV, "DSM and Roquette to start bio-based succinic acid joint venture," Heerlen, The Netherlands, June 2010.

[50] Cargill, Inc, "Cargill and Novozymes to enable production of acrylic acid via $3 \mathrm{HPA}$ from renewable raw materials," Minneapolis, Minn, USA and Copenhagen, Denmark, January 2008.

[51] Royal Dutch Shell plc, "Shell and Virent expand their collaboration on Advanced Biofuels," The Hague, Netherlands, June 2010 .

[52] E. I. du Pont de Nemours and Company, DuPont and Genencor Create World-Leading Cellulosic Ethanol Company, Wilmington, Del, USA and Copenhagen, Denmark, 2008.

[53] AB Perstorp, "Supporting biogas development for return to bio-based chemicals," December 2009, http://www.perstorp .com/News/In\%20Focus\%20List/First\%20In\%20Focus/200912-15\%20Biogas.aspx.

[54] Plastics Europe-Association of Plastics Manufacturers, "Environmental Product Declarations of the European
Plastics Manufacturers-Linear low density polyethylene (LLDPE)," Brussels, Belgium, November 2008.

[55] The Dow Chemical Co, "Estimated by Dow Hydrocarbon and Energy Team," Midland, Mich, USA, 2008.

[56] N. Denis, A. Meiser, J. Riese, and U. Weihe, "McKinsey \& Company-setting the right course in the biobased bulks chemicals," McKinsey on Chemicals, pp. 22-27, 2008. 

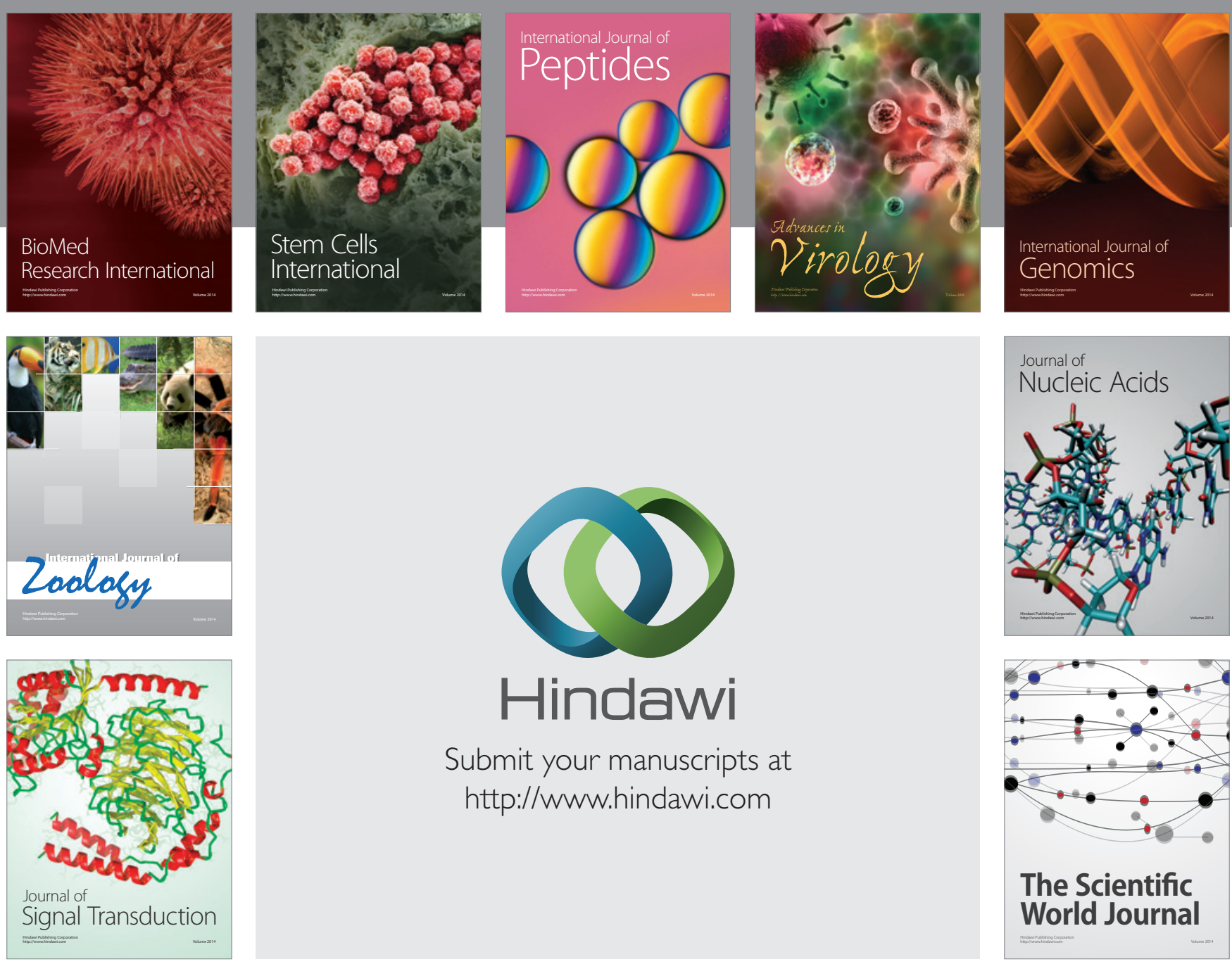

Submit your manuscripts at

http://www.hindawi.com
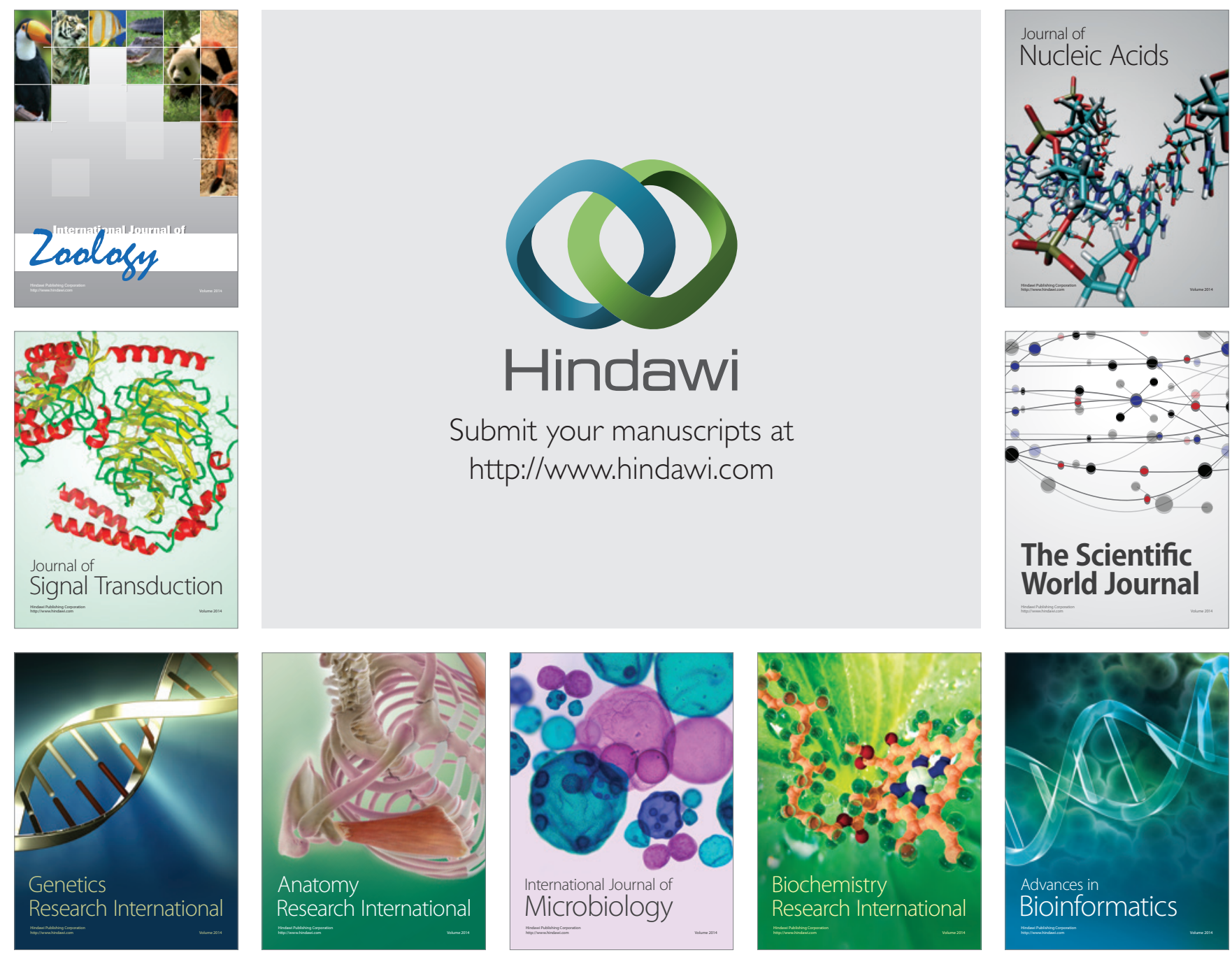

The Scientific World Journal
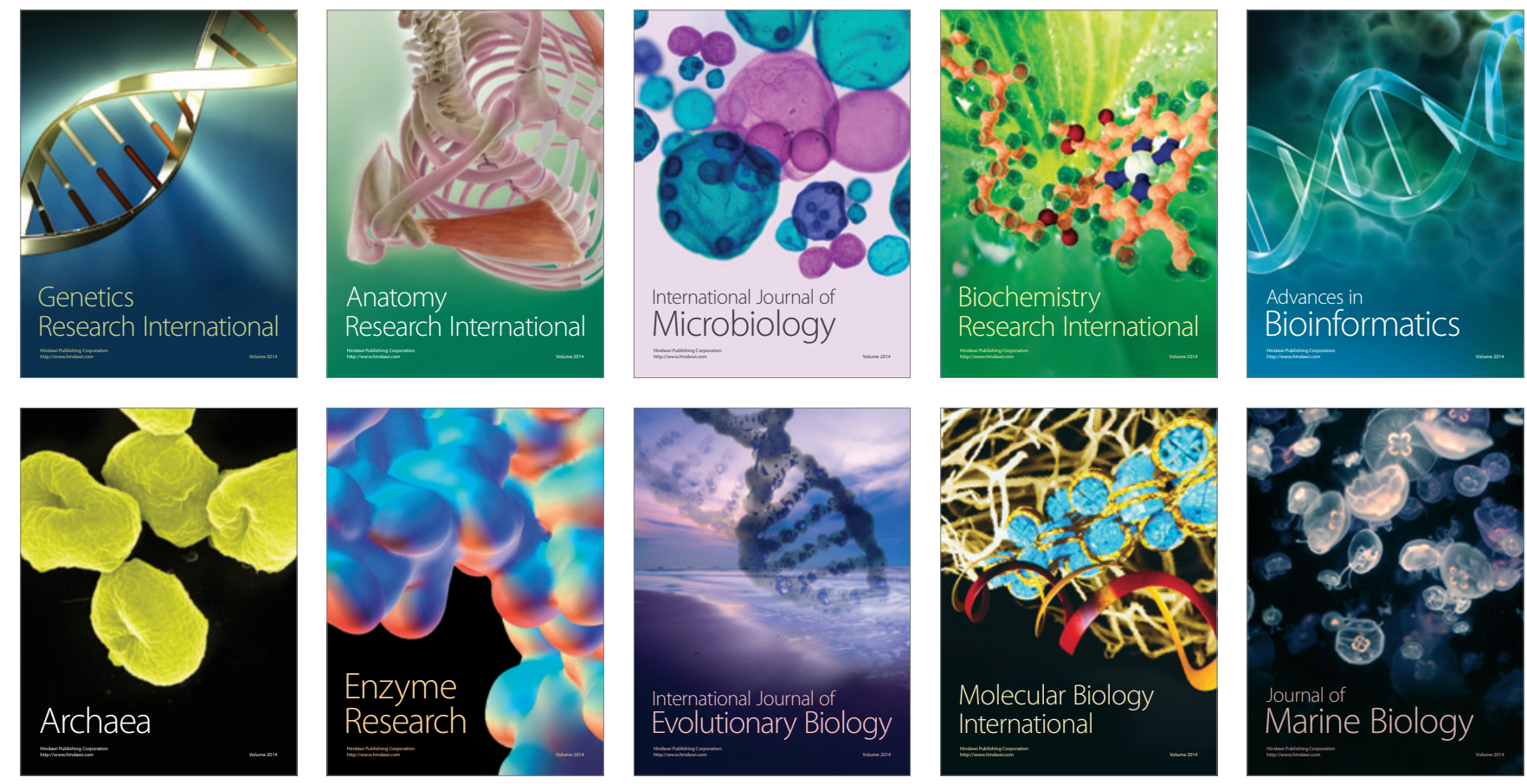